\title{
PERANAN RELATIONAL BENEFITS DALAM PENINGKATAN KEPUASAN DAN LOYALITAS PELANGGAN MEBEL LAMONGAN
}

\author{
Mohammad Yaskun \\ Program Studi Manajemen Fakultas Ekonomi Universitas Islam Lamongan \\ E-mail: \\ m.yaskun@unisla.ac.id
}

\begin{abstract}
ABSTRAK
Memberikan kepuasan secara konsisten kepada pelanggan dapat membuat pelanggan menjadi loyal kepada perusahaan. Sikap loyal pelanggan kepada perusahaan akan sangat membantu perusahaan untuk dapat bertahan dalam persaingan bisnis karena pelanggan merupakan sumber pendapatan dari perusahaan. Relationship marketing adalah salah satu strategi pemasaran yang bisa digunakan untuk mencapai tujuan tersebut. Melalui strategi relational benefits perusahaan dapat memberikan manfaat atas hubungan antara perusahaan dan pelanggan. Penelitian ini dilakukan di perusahaan mebel di Lamongan dengan responden sebanyak 202 orang. Hasil penelitian menunjukkan bahwa confidence benefits dan social benefits berpengaruh positif dan signifikan terhadap kepuasan pelanggan dan loyalitas pelanggan mebel. Special treatment benefits berpengaruh positif dan signifikan terhadap kepuasan pelanggan akan tetapi tidak berpengaruh signifikan terhadap loyalitas pelanggan mebel. Selanjutnya, kepuasan pelanggan berpengaruh positif dan signifikan terhadap loyalitas pelanggan mebel.
\end{abstract}

Kata kunci: Relational benefits, kepuasan pelanggan, loyalitas pelanggan.

\section{ABSTRACT}

Providing customer satisfaction consistently could make customers become loyal to the company. Loyal customers were the source of income and they would help the company to survive in the business competition. Relationship marketing was a strategy that can be used to achieve these goals, through relational benefits strategy. The company could give the benefit from relationship between companies and customers. This study analyzed relationship marketing in the furniture company in Lamongan through 202 respondents. The results show that confidence benefits and social benefits have positive effect on customer satisfaction and customer loyalty furniture. Special treatment benefits had positive effect on customer satisfaction but had no significant effect on 
customer loyalty furniture. Customer satisfaction had positive impact to customer loyalty furniture significantly.

Keywords: Relational benefits, customer satisfaction, customer loyalty.

\section{Pendahuluan}

Persaingan merupakan hal yang tidak dapat dihindari oleh para pelaku bisnis. Dalam menghadapi persaingan, perusahaan dituntut untuk mampu senantiasa memberikan kepuasaan bagi pelanggan, karena pelanggan merupakan sumber pendapatan dari perusahaan. Memberikan kepuasan secara konsisten kepada pelanggan, dapat membuat pelanggan menjadi loyal kepada perusahaan. Sikap loyal pelanggan kepada perusahaan akan sangat membantu perusahaan untuk dapat bertahan di dalam persaingan bisnis (Leverin dan Liljander, 2006). Loyalitas tidak dapat muncul dalam waktu yang singkat, perusahaan harus dapat secara konsisten menjaga kepuasan pelanggan dalam jangka panjang dan memiliki pelanggan yang loyal tentu akan sangat menguntungkan bagi perusahaan (Eisingerich dan Bell, 2006). Kepuasaan pelanggan merupakan suatu hal yang sangat krusial dalam menentukan sukses atau tidaknya suatu bisnis (Kau dan Elizabeth, 2006).

Memberikan kepuasan secara konsisten kepada pelanggan bukanlah perkara mudah. Prayoga (2010) berpendapat bahwa perubahaan yang terjadi kini cenderung membuat pelanggan semakin mudah dalam menentukan pilihan dan mengambil suatu keputusan, sebab mudahnya mendapatkan informasi membuat pelanggan semakin pintar, dan mampu mengevaluasi produk mana yang mampu memenuhi harapannya atas apa yang dijanjikan oleh pemasar dalam kegiatan komunikasi pemasaran. Menghadapi tantangan tersebut, perusahaan harus mulai melakukan penyesuain strategi, perusahaan yang dulunya lebih berfokus pada kegiatan transaksional kini harus mulai beralih pada kegiatan relationship guna mendekatkan diri dengan konsumen dan lebih mengetahui apa kebutuhan saat ini serta dapat memberikan manfaat kepada konsumen atas hubungan yang dirajut oleh perusahaan dan konsumen (Thurau, Thorsten, Kevin P. Gwinner, dan Dwayne D. Gremler, 2002).

Menurut Zheithaml, Valerie A., Mary Jo Bitner, dan Dwyne D. Gremler. (2006:184) Relationship marketing adalah salah satu strategi perusahaan dengan menjaga hubungan yang baik dengan pelanggan dalam jangka panjang. Strategi ini lebih memfokuskan pada bagaimana menjaga pelanggan yang sudah ada, agar tidak berpindah ke produk pesaing. Wibowo (2009) menyatakan bahwa relationship marketing adalah usaha untuk menarik, memelihara, dan meningkatkan hubungan jangka panjang dengan pelanggan. Oleh sebab itu, penting bagi perusahaan untuk lebih peduli pada pelanggan, karena salah satu faktor kunci perusahaan untuk dapat bertahan pada pasar yang sudah ada saat ini adalah dengan menjaga dan mempertahankan hubungan jangka panjang dengan para pelanggan (Perrien dan Richard, 1995).

Menurut Palmatier et al. (2006) relationship marketing adalah filosofi dalam melakukan bisnis berorientasi strategis, yang berfokus pada menjaga dan meningkatkan kualitas hubungan dengan pelanggan saat ini bukan berfokus pada usaha untuk memperoleh pelanggan baru. Filosofi ini mengasumsikan bahwa banyak pelanggan dan pelanggan bisnis lebih memilih untuk memiliki hubungan yang berkelanjutan dengan satu perusahaan saja daripada harus berpindah-pindah pada perusahaan lain, selama perusahaan tersebut mampu untuk memberikan nilai dan memenuhi harapan dari pelanggan, oleh karena itu menjaga pelanggan saat ini akan membuat biaya yang harus dikeluarkan oleh perusahan akan jauh lebih sedikit dibandingkan dengan mencoba untuk menarik pelanggan yang baru dengan menggunakan komunikasi pemasaran yang konvensional seperti iklan (Sui dan Baloglu, 2003). Untuk itulah perusahaan harus 
dapat memberikan suatu manfaat atau benefits kepada pelanggan dari hubungan yang dibangun kepada pelanggan (Rauyruen dan Miller, 2007). Pemasar yang sukses akan bekerja dengan menggunakan strategi yang efektif untuk mempertahankan pelanggan dengan senantiasa memberikan kepuasan dalam jangka panjang (Thurau dan Klee, 1997).

Memberikan manfaat dari sebuah hubungan atau relational benefits sesungguhnya dapat menguntungkan kedua belah pihak, baik pelanggan maupun perusahaan (Molina et al., 2009). Keuntungan yang dimaksud adalah ketika perusahaan menerapkan strategi relationship marketing, perusahaan akan mampu mengetahui secara utuh dan lebih lengkap tentang apa yang pelanggan sebenarnya butuhkan sehingga perusahaan akan menciptakan solusi berupa produk untuk membantu pelanggan dalam memenuhi kebutuhannya. Dengan harapan hal tersebut akan membuat pelanggan puas dan menjadi loyal pada perusahaan. Di satu sisi, pelanggan melalui hubungan ini, akan memperoleh manfaat kepuasaan bahwa seluruh kebutuhannya akan dipenuhi oleh perusahaan (Zeithaml et al., 2006:183). Muara dari hubungan ini adalah adanya hubungan yang saling menguntungkan diantara pelanggan dan perusahaan.

Beberapa pendekatan dapat digunakan dalam memberikan manfaat atas suatu hubungan atau relational benefits, namun yang umumnya digunakan adalah confidence benefits, social benefits dan special treatment benefits (Molina et al., 2009; Dimitriadis, 2010; Kinnar dan Capella, 2006; Molina et al., 2007). Confidence benefits merupakan salah satu manfaat hubungan berupa kepercayaan yang terjalin oleh perusahaan maupun pelanggan. Pelanggan akan merasa aman, ketika dilayani oleh perusahaan yang telah dipercaya, dan perusahaan akan lebih nyaman dalam memberikan pelayanan ketika telah mendapatkan kepercayaan dari pelangggan. Social benefits merupakan bentuk manfaat dari sebuah hubungan berupa keakraban yang terjalin oleh pelanggan dan perusahaan. Manfaat sosial akan membuat pelanggan lebih nyaman dalam menyampaikan keluhan serta masalah yang telah dihadapi, dan perusahaan akan mampu lebih akurat dalam memecahkan masalah yang dihadapi oleh pelanggan. Special treatment benefits merupakan bentuk manfaat berupa perlakuan istimewa yang diterima oleh pelanggan. Manfaat perlakuan istimewa diharapkan dapat membuat konsumen merasa lebih dihargai dan akhirnya menjadi loyal kepada perusahaan yang memberikannya perlakukan istimewa.

\section{Kerangka Konseptual}

Dalam Dalam menyusun model pengaruh konstruk relational benefits dengan konstruk kepuasan serta loyalitas pelanggan, penelitian ini mengadopsi dan mengadaptasi beberapa model penelitian yang relevan dengan topik ini. Model penelitian mengenai relational benefits yang digolongkan melalui tiga buah konstruk yaitu confidence benefits, social benefits, dan special treatment benefits, merupakan adopsi dari penelitian yang dilakukan oleh Thurau et al. pada tahun 2002. Penggolongan konstruk relational benefits menjadi confidence benefits, social benefits, dan special treatment benefits juga dilakukan oleh Molina et al. (2009), Dimitriadis (2010), Yen dan Gwinner, (2003), Kinnard dan Capella (2006), Molina et al. (2007), dan Zeithaml et al. (2006).

Confidence benefits merupakan kemampuan perusahaan dalam mengurangi kecemasan pelanggan sehingga pelanggan memberikan kepercayan dan keyakinan kepada perusahan penyedia produk. Jika dikaitkan dengan objek penelitian ini yaitu industri mebel, maka confidence benefits menjadi hal yang penting bagi pelanggan industri mebel untuk dapat merasa nyaman dan segala kecemasannya berkurang karena kepercayaan dan keyakinan terhadap reputasi dari perusahaan. 
Social benefits merupakan manfaat sosial ketika perusahaan melalui karyawan mampu menjalin hubungan yang baik dengan pelanggan. Zeithaml et al. (2006:184) menyatakan bahwa hubungan yang baik akan membuat pelanggan merasa lebih nyaman dalam beriteraksi. Hubungan personal menjadi penting bagi karyawan industri mebel pada perusahaan yang menjadi objek pada penelitian, agar dapat membangun hubungan personal yang baik dengan pelanggan.

Special treatment benefits merupakan sebuah bentuk perlakuan istimewa bagi pelanggan berupa pelayanan yang berbeda dari pelanggan lain pada umumnya (Thurau et al., 2002). Berkaitan dengan lokasi penelitian ini pada industri mebel, maka perusahaan harus dapat memberikan pelayanan diluar manfaat inti dari produk yang digunakan pelanggan, agar pelanggan nantinya mendapatkan hal yang berbeda dan lebih ketika menggunakan produk di perusahaan tersebut.

Terdapat beberapa penelitian lainnya yang menggunakan konstruk relational benefits namun terdapat juga penelitian yang menggolongkan konstruk dengan jumlah yang lebih dari tiga, misalkan Yu Kevin dan Yang (2009), selain menggunakan confidence benefits, social benefits, dan special treatment benefits juga menambahkan konstruk comfort benefits, information benefits, identity related benefits, interactive benefits, dan sharing benefits. Namun, karena definisi dari tambahan konstruk tersebut hampir sama dan manfaat hubungan telah tercakup dalam tiga konstruk yaitu confidence benefits, social benefits, dan special treatment benefits, maka model relational benefit yang digunakan dalam penelitian ini adalah confidence benefits, social benefits, dan special treatment benefits.

Dalam penelitian yang berkaitan dengan relationship marketing, kepuasan pelanggan merupakan konstruk dari relational quality (Leverin dan Liljander, 2006; Alrubaiee dan Nazer, 2010). Relational quality akan muncul ketika relational benefits telah didapatkan, dan muara dari hubungan tersebut adalah relational outcomes (Thurau et al., 2002). Sebelumnya dalam banyak penelitian, beberapa konstruk lain selain kepuasan pelanggan banyak digunakan untuk mengukur relational quality (Alrubaiee dan Nazer, 2010), seperti trust, commitmen, bonding, dan communication. Namun, karena indikator-indikator konstruk tersebut hampir sama dengan konstruk relational benefits, maka konstruk tersebut tidak digunakan dalam penelitian ini.

Loyalitas dapat digolongkan sebagai relational outcomes dari relationship marketing. Selain loyalitas, terdapat word of mouth yang juga merupakan bagian dari relational outcomes (Thurau et al., 2002). Namun, karena di dalam indikator loyalitas sudah terdapat unsur word of mouth, yaitu word of mouth dalam bentuk positif, maka konstruk word of mouth tidak dimasukan dalam penelitian ini.

Berdasarkan beberapa penelitian serta kajian teori diatas, maka dapat disusun model penelitian sebagai berikut.

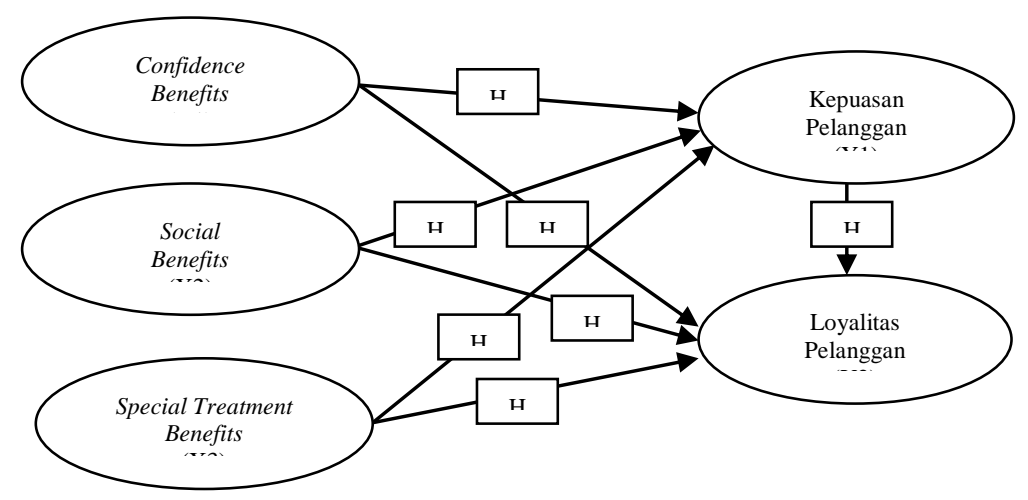

Gambar 1. Kerangka Konseptual 


\section{Hipotesis Penelitian}

Confidence Benefits diartikan sebagai : "feelings of reduced anxiety, trust, and confidence in the provider" Grembler et al. (1998), dapat diartikan bahwa dengan adanya manfaat keyakinan, pelanggan akan merasa tidak cemas serta percaya dan yakin dengan perusahan penyedia jasa dalam memberikan layanannya, sehingga dapat membuat pelanggan puas sesuai dengan harapannya. Hipotesis pertama, confidence benefits berpengaruh positif dan signifikan terhadap kepuasan pelanggan. Penelitian yang dilakukan oleh Thurau et al. (2002), Kinard dan Capella (2006), Molina et al. (2007), Yen dan Gwinner (2003), Prayustika (2010), Briliana (2013), dan Prayogi (2015) menunjukkan bahwa confidence benefits berpengaruh positif dan signifikan terhadap kepuasan pelanggan. H1: Confidencen benefits berpengaruh positif signifikan terhadap kepuasan pelanggan.

Social benefits mampu membuat hubungan pelanggan dengan perusahaan menjadi lebih hangat. Dengan adanya rasa kekeluargaan, akan membuat pelanggan jauh lebih nyaman dalam berinteraksi dengan perusahaan (Dimitriadis, 2010). Hipotesis kedua, social benefits berpengaruh positif signifikan terhadap kepuasan pelanggan. Untuk konstruk social benefits beberapa penelitian sebelumnya memberikan pengaruh positif dan signifikan terhadap kepuasan pelanggan. Diantaranya adalah penelitian yang dilakukan oleh Navaro et al. (2004), Briliana (2013), dan Prayogi (2015). H2: Social benefits berpengaruh positif signifikan terhadap kepuasan pelanggan.

Thurau et al. (2002) menyatakan bahwa special treatment benefits merupakan kombinasi dari keuntungan secara ekonomis maupun keuntungan customization bagi pelanggan. Customization yang dimaksud adalah pelanggan akan mendapat harga yang berbeda dan juga penawaran produk yang diberikan kepadanya tidak didapat oleh semua pelanggan secara umum karena dalam konteks ini pelanggan selalu berharap mereka mendapatkan keuntungan secara finansial. Hal ini pun sejalan dengan pernyataan dari Dimitriadis (2010) yang menekankan pentingnya customization bagi pelanggaan. Perlakuan umum sebagai pemenuhan kebutuhan dasar dari setiap pelanggan memang penting untuk dipenuhi, namun perlakuan istimewa terhadap konsumen selektif penting dilakukan dalam upaya menumbuhkan kepuasan pelanggan. Hipotess ketiga, special treatment benefits berpengaruh positif dan signifikan terhadap kepuasan pelanggan. Penelitian yang dilakukan oleh Briliana (2013) dan Prayogi (2015) menunjukkan bahwa konstruk special treatment benefits berpengaruh positif dan signifikan terhadap kepuasan pelanggan. H3: Special treatment benefits berpengaruh positif signifikan terhadap kepuasan pelanggan.

Thurau et al. (2002) menyatakan bahwa konsumen yang mengembangkan kepercayaan pada penyedia jasa berdasarkan pengalaman baik mereka dengan penyedia jasa mempunyai alasan yang baik untuk tetap melanjutkan hubungan tersebut. Pengalaman yang baik terutama harus dari konsumen itu sendiri, karena komitmen dari dalam itu adalah yang paling kuat bagi konsumen agar loyal pada penyedia jasa. Hipotesis keempat, confidence benefits berpengaruh positif dan signifikan terhadap loyalitas pelanggan. Adanya pengaruh positif dan signifikan confidence benefits terhadap loyalitas dikemukakan oleh Thurau et al. (2002), Yen dan Gwinner (2003), Kinard dan Capella (2006), Molina et al. (2009), dan Briliana (2013). H4: Confidence benefits berpengaruh positif dan signifikan terhadap loyalitas pelanggan.

Zeithaml et al. (2006:184) menyatakan bahwa social benefits adalah ketika perusahaan mampu menjalin hubungan yang baik dengan konsumen atau pelanggan mereka. Hubungan ini membuat peluang konsumen untuk beralih (brand switching) semakin kecil, walaupun terdapat pesaing atau kompetitor yang memiliki produk yang lebih baik, ataupun berani memberikan harga yang lebih murah. Hubungan pribadi 
dapat mengembangkan untuk bisnis ke pelanggan. Manfaat dukungan sosial yang dihasilkan dari hubungan ini penting untuk meningkatkan kualitas konsumen dan di luar manfaat teknis dari layanan yang disediakan. Seringkali hubungan pendekatan yang professional dari perusahaan terhadap pelanggan yang berkembang merupakan dasar untuk menciptakan loyalitas pelanggan. Hipotesis kelima, social benefits berpengaruh positif dan signifikan terhadap loyalitas. Adanya pengaruh positif dan signifikan social benefits terhadap loyalitas dikemukakan oleh Thurau et al. (2002) dan Navaro et al. (2004). H5: Social benefits berpengaruh positif dan signifikan terhadap loyalitas pelanggan.

Menurut Zeithaml et al. (2006:184) perlakuan istimewa mencakup di dalamnya adalah pemberian harga spesial maupun perlakuan khusus yang tidak diterima oleh pelanggan kebanyakan. Dikatakan juga bahwa manfaat ini kadang tidak begitu penting dibandingkan manfaat-manfaat lainnya. Meskipun manfaat perlakuan istimewa dapat dengan jelas dijadikan sebagai unsur kritis untuk membentuk loyalitas pelanggan.

Hipotess keenam, special treatment benefits berpengaruh positif dan signifikan terhadap loyalitas pelanggan. Penelitian yang menemukan adanya pengaruh positif dan signifikan special treatment benefits terhadap loyalitas dikemukakan antara lain oleh Yen dan Gwinner (2003), Molina et al. (2009), Briliana (2013), dan Prayogi (2015). H6: Special treatment benefits berpengaruh positif dan signifikan terhadap loyalitas pelanggan.

Menurut Lovelock (2007:102) apabila pelanggan merasakan kinerja berada dibawah harapan, maka pelanggan akan merasa tidak puas. Begitupun sebaliknya, bila kinerja sama dengan harapan atau melampaui harapan, maka pelanggan akan merasa puas dan pelanggan akan menjadi loyal. Penelitian tentang pengaruh kepuasan terhadap loyalitas diantaranya dikembangkan oleh Thurau et al. (2002), Yen dan Gwinner (2003), Yen et al. (2009), Navaro et al. (2004), Prayustika (2010), Briliana (2013), dan Prayogi (2015). Keseluruhan hasil riset tersebut mengemukakan bahwa kepuasan berpengaruh positif dan signifikan terhadap loyalitas pelanggan. Hubungan antara kepuasan dan loyalitas adalah saat di mana konsumen mencapai tingkat kepuasan tertinggi yang menimbulkan ikatan emosi yang kuat dan komitmen jangka panjang dengan merek perusahaan. Konsep tersebut menunjukkan bahwa adanya hubungan antara kepuasan terhadap kesetiaan konsumen. H7: Kepuasan berpengaruh positif dan signifikan terhadap loyalitas pelanggan.

\section{Metode Penelitian}

Penelitian ini dilakukan pada industri mebel di Lamongan yang berjumlah 10 usaha mebel, dengan mengambil subjek para pelanggan industri mebel tersebut. Penelitian ini dilakukan dengan alasan perusahaan yang diteliti merupakan perusahaan manufaktur dan mengaplikasikan strategi bisnis baru yaitu relationship marketing melalui relational benefits. Penilaian pelanggan industri mebel di Lamongan dalam menilai relational benefits yang terdiri atas confidence benefits, social benefits, dan special treatment benefits yang didapatkan ketika menggunakan produk industri mebel di Lamongan untuk selanjutnya diukur kepuasan pelanggan dan loyalitas pelanggan.

Menurut Sugiyono (2014:80) mengemukakan bahwa populasi adalah wilayah generalisasi yang terdiri atas objek dan subjek yang mempunyai kualitas dan karakteristik tertentu yang ditetapkan oleh peneliti untuk dipelajari kemudian ditarik kesimpulannya. Yang menjadi populasi dalam penelitian ini adalah seluruh pelanggan yang pernah membeli produk mebel lebih dari dua kali pembelian pada industri mebel yang ada di Lamongan. Dari data yang berhasil dihimpun, ada 408 pelanggan yang tersebar pada 10 perusahaan mebel di seluruh wilayah kabupaten Lamongan. 
Sampel merupakan bagian dari jumlah dan karakteristik yang dimilki oleh populasi tersebut (Sugiyono, 2014:81). Sampel merupakan bagian kecil dari populasi yang mewaliki populasi yang diteliti sehingga hasil penelitian yang menggunakan sampel dianggap mewakili populasi yang diteliti. Besarnya ukuran sampel yang akan diteliti dari suatu populasi dapat digunakan rumus pendekatan Slovin (Umar, 2005:146), sebagai berikut :

$$
\mathrm{n}=\frac{\mathrm{N}}{1+\mathrm{N} \cdot \mathrm{e}^{2}}
$$

Keterangannya sebagai berikut :

$$
\begin{aligned}
& \mathrm{n}=\text { Ukuran Sampel } \\
& \mathrm{N}=\text { Ukuran Populasi } \\
& \mathrm{e}=5 \% \text { (Prosentase tingkat kesalahan pengambilan sampel) }
\end{aligned}
$$

Berdasarkan rumus pendekatan Slovin diatas, maka yang menjadi sampel dalam penelitian ini sebanyak:

$$
\begin{aligned}
& \mathrm{n}=\frac{\mathrm{N}}{1+\mathrm{N} \cdot \mathrm{e}^{2}} \\
& \mathrm{n}=\frac{408}{1+408 \cdot(0,05)^{2}} \\
& \mathrm{n}=\frac{408}{2,02}
\end{aligned}
$$$$
\mathrm{n}=201,98=202 \text { responden }
$$

Sesuai dengan karakteristik populasi yang terbagi dalam 10 perusahaan mebel yang berbeda, maka teknik pengambilan sampel yang digunakan adalah Stratified Random Sampling, yaitu pemilihan sampel yang diaplikasikan pada populasi yang bersifat heterogen. Sampel akan dilakukan secara random sehingga setiap anggota yang ada disetiap kelompok memliki peluang yang sama besar untuk menjadi responden dalam penelitian ini.

Identifikasi variabel dan indikator variabel disajikan dalam Tabel 1.

Tabel 1. Identifikasi Konstruk

\begin{tabular}{|c|c|l|c|}
\hline $\begin{array}{c}\text { Jenis } \\
\text { Konstru } \\
\mathbf{k}\end{array}$ & \multicolumn{1}{|c|}{$\begin{array}{c}\text { Nama Konstruk } \\
\text { (Sumber) }\end{array}$} & Keterangan & Simbol \\
\hline Eksogen & \multicolumn{1}{c|}{ Confidence Benefits } \\
& (Thurau et al., 2002; & $\begin{array}{l}\text { 1) Kepercayaan terhadap } \\
\text { karyawan }\end{array}$ & $\mathrm{X} 1.1$ \\
& Kinard dan Capella, 2006; & 2) Kepercayaan terhadap reputasi & $\mathrm{X} 1.2$ \\
& Molina et al., 2009). & $\begin{array}{l}\text { 3) Keandalan karyawan } \\
\text { 4) Ketepatan janji pada pelanggan } \\
\text { atas produk mebel }\end{array}$ & $\mathrm{X} 1.4$ \\
& Social Benefits & & \\
\hline
\end{tabular}




\begin{tabular}{|c|c|c|c|}
\hline & $\begin{array}{l}\text { (Dimitriadis, } 2010 \text {; } \\
\text { Kinard dan Capella, 2006; } \\
\text { Molina et al., 2009). } \\
\text { - Special Treatment }\end{array}$ & $\begin{array}{l}\text { 1) Perlakuan personal yang baik } \\
\text { 2) Hubungan pertemanan } \\
\text { 3) Pengenalan identitas pelanggan } \\
\text { oleh karyawan } \\
\text { 4) Keakraban konsumen dengan } \\
\text { karyawan industri mebel }\end{array}$ & $\begin{array}{l}X 2.1 \\
X 2.2 \\
X 2.3 \\
X 2.4\end{array}$ \\
\hline & $\begin{array}{l}\quad \text { Special Treatment } \\
\text { Benefits (Molina et al., } \\
\text { 2009; Thurau et al., 2002; } \\
\text { Dimitriadis, 2010). }\end{array}$ & $\begin{array}{l}\text { 1) Prioritas dalam list } \\
\text { 2) Potongan harga } \\
\text { 3) Produk/layanan yang sigap } \\
\text { 4) Harga yang murah } \\
\text { 5) Produk yang lebih lengkap }\end{array}$ & $\begin{array}{l}\text { X3.1 } \\
\text { X3.2 } \\
\text { X3.3 } \\
\text { X3.4 } \\
\text { X3.5 }\end{array}$ \\
\hline $\begin{array}{c}\text { Jenis } \\
\text { Konstru } \\
\mathbf{k} \\
\end{array}$ & $\begin{array}{c}\text { Nama Konstruk } \\
\text { (Sumber) }\end{array}$ & Keterangan & Simbol \\
\hline \multirow[t]{2}{*}{ Endogen } & \multirow[t]{2}{*}{$\begin{array}{l}\text { - Kepuasan Pelanggan } \\
\text { (Ndubisi dan Chan Wah, } \\
\text { 2005; Duck Kim, 2005). }\end{array}$} & $\begin{array}{l}\text { 1) Puas dengan produk } \\
\text { 2) Pengalaman setelah } \\
\text { mendapatkan produk } \\
\text { 3) Puas dengan perlakuan } \\
\text { Perusahaan } \\
\text { 4) Keputusan yang tepat } \\
\text { 5) Puas dengan keseluruhan } \\
\text { produk }\end{array}$ & $\begin{array}{l}\text { Y1.1 } \\
\text { Y1.2 } \\
\text { Y1.3 } \\
\text { Y1.4 } \\
\text { Y1.5 }\end{array}$ \\
\hline & & $\begin{array}{l}\text { 1) Menggunakan kembali } \\
\text { 2) Pilihan utama } \\
\text { 3) Tidak akan beralih } \\
\text { 4) Merekomendasikan mebel }\end{array}$ & $\begin{array}{l}\text { Y2.1 } \\
\text { Y2.2 } \\
\text { Y2.3 } \\
\text { Y2.4 }\end{array}$ \\
\hline
\end{tabular}

\section{Metode Analisa Data}

Metode analisis yang digunakan untuk menganalisis data adalah Structural Equation Modelling (SEM). Menurut Ferdinand (2002:70), SEM merupakan alat atau teknik analisis data yang terdiri atas dua tahap dasar yaitu tahap model pengukuran (Measurement Model) melalui Confirmatory Factor Analysis dan tahap persamaan struktural model (Structural Equation Model). Tujuan utamanya adalah untuk menguji kesesuaian model tersebut (fit) dengan data yang sah. Data dalam penelitian ini dianalilis dengan mengunakan Structural Equation Modelling (SEM) dengan aplikasi Software Analysis Moment of Structure (AMOS) 4.01.

\section{Hasil Penelitian dan Pembahasan}

\section{Tahap Analisis Model Persamaan Struktural}

Setelah model dianalisis melalui Confirmatory Factor Analysis, diketahui bahwa masing-masing variabel dapat digunakan untuk mendefinisikan sebuah konstruk laten, maka model tersebut dapat dianalisis. Pengujian untuk model SEM dilakukan pada indeks-indeks Goodness of Fit. Salah satu alat uji yaitu Chi square bersifat sangat sensitif terhadap besarnya sampel. Nilai Chi square merupakan alat uji untuk mengukur overall fit. Hasil uji Chi square dipandang baik jika nilainya semakin rendah (Ferdinand, 2002:55).

Kelemahan dari alat uji Chi square perlu diatasi, salah satunya dengan menggunakan alat uji Root Mean Square of Approximation (RMSEA) yang lebih independen terhadap ukuran sampel yang digunakan. RMSEA merupakan uji kesesuaian close fit, tidak seperti Chi square yang merupakan uji kesesuaian exact fit. Jadi uji kesesuaian yang exact fit kurang realistis bila dibandingkan dengan uji 
kesesuaian yang close fit karena lebih realistis untuk mengukur tingkat aplikasi model terhadap data. Selain RMSEA, indeks Goodness of Fit Indeks (GFI), Tucker Lewis Index (TLI) juga sangat dianjurkan untuk dipergunakan karena indeks ini tidak sensitif terhadap besarnya sampel dan kurang dipengaruhi oleh kerumitan suatu model. Hasil analisis persamaan struktural pada model dapat dilihat pada Gambar 2.

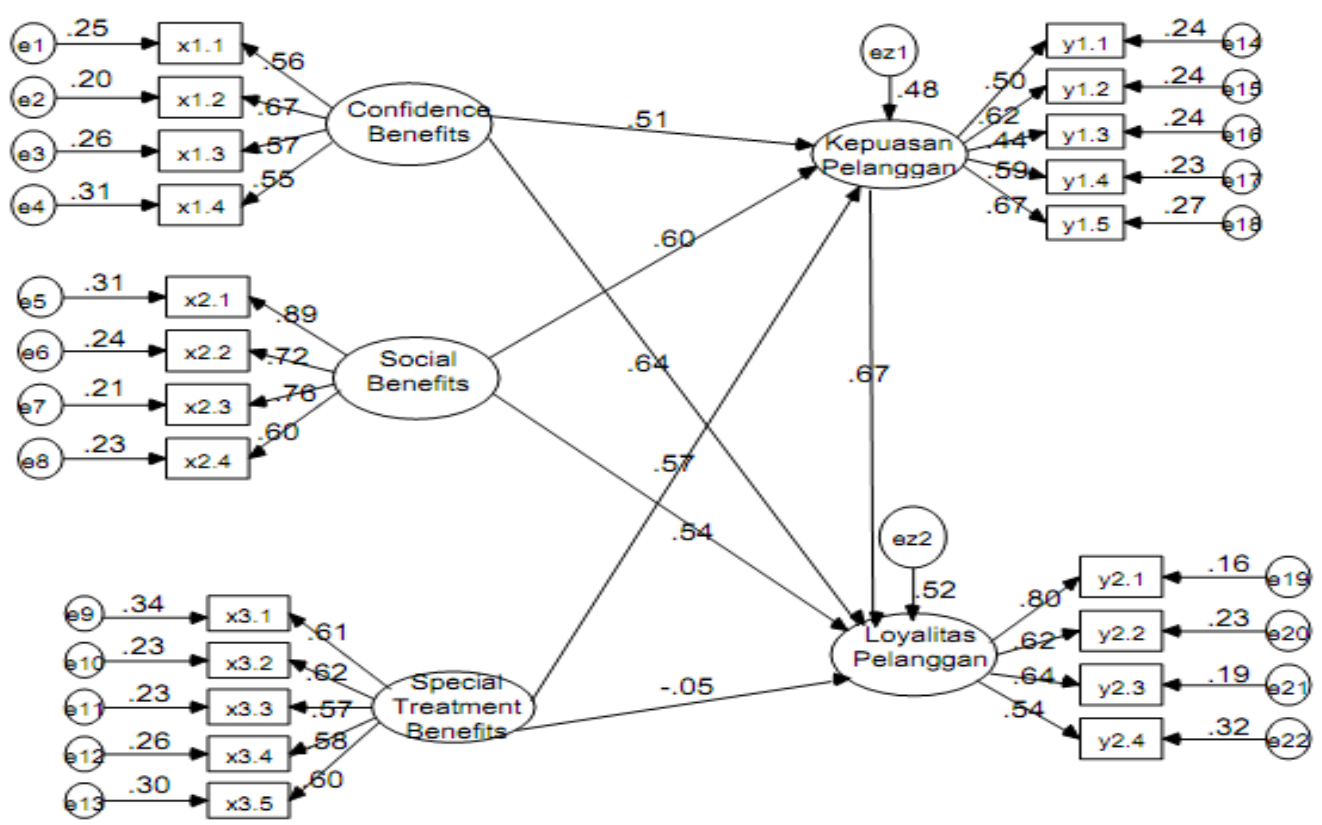

UJI KETEPATAN MODEL

Chi-Square $=309.741$
Probability $=0.090$
CMIN/DF $=1.556$
GFI $=0.879$
AGFI $=0.846$
TLI $=0.955$
CFI $=0.961$
RMSEA $=0.053$

\section{Gambar 2. Hasil Analisis Model Persamaan Struktural}

Hasil uji kelayakan model struktural secara ringkas ditampilkan pada Tabel 3. Berdasarkan data dalam Tabel 3, indeks GFI dan AGFI, lebih kecil dari 0,90, yaitu masing-masing sebesar 0,879 dan 0,846, nilai ini masih dapat diterima dengan katagori cukup baik. Indeks TLI dan CFI telah memenuhi syarat karena nilai kedua indeks pada model memiliki nilai yang lebih besar dari 0,95, yaitu masing-masing sebesar 0,955 dan 0,961. Berdasarkan indeks CMIN/DF, dapat dilihat bahwa indeks pada model memiliki nilai $\leq 2,00$, yaitu 1,556, indeks RMSEA dari model juga lebih kecil dari 0,08 yakni sebesar 0,053, sehingga dapat dinyatakan bahwa secara keseluruhan model telah fit.

Pengujian terhadap hipotesis penelitian didasari oleh hasil analisis yang diperoleh dari hubungan kausalitas antar konstruk penelitian seperti disajikan pada Tabel 4. Berdasarkan Tabel 4, dapat dilihat bahwa dari tujuh hipotesis yang telah diuji secara keseluruhan terdapat enam hipotesis yang diterima yaitu konstruk confidence benefits berpengaruh positif dan signifikan terhadap konstruk kepuasan dengan nilai koefisien 0,510, lalu konstruk social benefits yang berpengaruh positif dan signifikan terhadap konstruk kepuasan dengan nilai koefesien 0,596, serta untuk konstruk special 
treatment benefits berpengaruh positif dan signifikan terhadap konstruk kepuasan karena memiliki $p$ value 0,05 lebih kecil dari nilai koefesien 0,574.

Konstruk confidence benefits juga berpengaruh positif dan signifikan terhadap konstruk loyalitas dengan nilai koefisien sebesar 0,643, dan konstruk social benefits yang berpengaruh positif dan signifikan terhadap konstruk loyalitas dengan nilai koefisien 0,536 dan $p$ value 0,48 di bawah 0,05 , konstruk kepuasan juga berpengaruh positif dan signifikan terhadap konstruk loyalitas dengan nilai koefisien 0,672.

Untuk satu hipotesis lainnya yang diuji hipotesisnya tidak dapat diterima, konstruk special treatment benefits memiliki pengaruh negatif namun tidak signifikan terhadap konstruk kepuasan karena memiliki nilai koefesien -0,053 lebih kecil dari $p$ value 0,000 .

Tabel 2. Uji Kelayakan Model Struktural

\begin{tabular}{|l|c|c|c|}
\hline \multicolumn{1}{|c|}{$\begin{array}{c}\text { Goodness of Fit } \\
\text { Index }\end{array}$} & Cut-off Value & $\begin{array}{c}\text { Hasil } \\
\text { Analisis }\end{array}$ & Keterangan \\
\hline $\mathrm{X}^{2}$ - Chi- Square & $\begin{array}{c}\text { Diharapkan nilai lebih } \\
\text { kecil }\end{array}$ & 309,741 & Baik \\
\hline $\begin{array}{l}\text { Significance } \\
\text { Probability }\end{array}$ & $\geq 0,05$ & 0,090 & Baik \\
\hline CMIN/DF & $\leq 2,00$ & 1,556 & Baik \\
\hline GFI & $\geq 0,90$ & 0,879 & Cukup Baik \\
\hline AGFI & $\geq 0,90$ & 0,846 & Cukup Baik \\
\hline TLI & $\geq 0,95$ & 0,955 & Baik \\
\hline CFI & $\geq 0,95$ & 0,961 & Baik \\
\hline RMSEA & $\leq 0,08$ & 0,053 & Baik \\
\hline
\end{tabular}

Tabel 3. Hasil Pengujian Hipotesis Penelitian

\begin{tabular}{|l|c|c|c|}
\hline \multicolumn{1}{|c|}{ Hubungan Konstruk } & Koefesien & $\begin{array}{c}\boldsymbol{P} \text { - } \\
\text { Value }\end{array}$ & Keterangan \\
\hline Kepuasan <---- Confident benefits & 0,510 & 0,000 & Signifikan \\
\hline Kepuasan <---- Social benefits & 0,596 & 0,000 & Signifikan \\
\hline $\begin{array}{l}\text { Kepuasan <---- Special treatment } \\
\text { benefits }\end{array}$ & 0,574 & 0,000 & Signifikan \\
\hline Loyalitas <---- Confident benefits & 0,643 & 0,000 & Signifikan \\
\hline Loyalitas <---- Social benefits & 0,536 & 0,000 & Signifikan \\
\hline $\begin{array}{l}\text { Loyalitas <---- Special treatment } \\
\text { benefits }\end{array}$ & $-0,053$ & 0,000 & $\begin{array}{c}\text { Tidak } \\
\text { Signifikan }\end{array}$ \\
\hline Loyalitas <---- Kepuasan & 0,672 & 0,000 & Signifikan \\
\hline
\end{tabular}

\section{Pembahasan}

Berdasarkan seluruh hasil penelitian terutama hasil pengujian hipotesis maka dapat dijelaskan pengaruh dari konstruk eksogen yang terdiri dari confidence benefits, social benefits, special treatment benefits terhadap variabel endogen yaitu kepuasan pelanggan dan loyalitas pelanggan.

Berdasarkan hasil pengujian hipotesis, dapat dijelaskan bahwa confidence benefits berpengaruh positif dan signifikan terhadap kepuasan pelanggaan industri mebel di Lamongan. Artinya, bahwa confidence benefits atau manfaat kepercayaan yang meliputi reputasi perusahaan, keandalan karyawan, ketepatan janji perusahaan, dan kepercayaan terhadap karyawan mebel, telah mampu membuat pelanggaan mebel di 
Lamongan puas. Selain itu, berdasarkan hasil penelitian juga dapat disimpulkan bahwa semakin baik manfaat kepercayaan yang diperoleh atau confidence benefits maka kepuasan yang akan dirasakan oleh pelanggan pelanggaan mebel di Lamongan akan semakin baik juga. Hal ini mendukung studi yang dilakukan oleh Thurau et al. (2002), Kinard dan Capella (2006), Molina et al. (2007), Yen dan Gwinner (2003), Prayustika (2010), Briliana (2013), dan Prayogi (2015).

Berdasarkan hasil penelitian, dapat dijelaskan bahwa social benefits yang meliputi perlakuan personal yang baik, hubungan pertemanan, pengenalan identitas pelanggan, dan keakraban konsumen dengan karyawan mebel berpengaruh positif dan signifikan terhadap kepuasan pelanggaan industri mebel di Lamongan karena memiliki $p$ value dibawah 0,050 . Artinya, bahwa semakin baik manfaat sosial yang diperoleh atau social benefits maka kepuasan yang akan dirasakan oleh pelanggan mebel di Lamongan akan semakin baik juga. Hasil penelitian ini mendukung studi yang dilakukan oleh Navaro et al. (2004), Briliana (2013), dan Prayogi (2015).

Berdasarkan hasil penelitian, dapat dijelaskan bahwa special treatment benefits yang meliputi prioritas pelanggan dalam list, potongan harga, produk/layanan yang sigap, harga yang murah, dan produk yang lebih lengkap berpengaruh positif dan signifikan terhadap kepuasan pelanggaan mebel di Lamongan karena memiliki $p$ value dibawah 0,050. Artinya, bahwa special treatment benefits atau manfaat perlakuan istimewa menjadi faktor penting dalam menentukan kepuasan pelanggan mebel di Lamongan. Perlakuan istimewa yang perusahaan berikan mampu memberikan kepuasan kepada para pelangganya. Penelitian ini mendukung hasil studi yang dilakukan oleh Thurau et al. (2002), Yen dan Gwinner (2003), Kinard dan Capella (2006), dan Molina et al. (2007).

Berdasarkan hasil penelitian, dapat dijelaskan bahwa confidence benefits berpengaruh positif dan signifikan terhadap loyalitas pelanggaan mebel di Lamongan. Artinya, bahwa confidence benefits atau manfaat kepercayaan yang meliputi reputasi perusahaan, keandalan karyawan, ketepatan janji perusahaan dan kepercayaan terhadap karyawan mebel, telah mampu membuat pelanggan mebel di Lamongan menjadi loyal. Selain itu, berdasarkan hasil penelitian juga dapat dijelaskan bahwa semakin baik manfaat kepercayaan yang terjalin atau confidence benefits maka loyalitas pelanggan mebel di Lamongan akan semakin baik juga. Hasil temuan ini mendukung studi yang dilakukan oleh Thurau et al. (2002), Yen and Gwinner (2003), Kinard dan Capella (2006), Molina et al. (2009), dan Prayogi (2015).

Berdasarkan hasil penelitian, dapat dijelaskan bahwa social benefits yang meliputi perlakuan personal yang baik, hubungan pertemanan, pengenalan identitas pelanggan, dan keakraban konsumen dengan karyawan mebel berpengaruh positif dan signifikan terhadap loyalitas pelanggaan mebel di Lamongan. Artinya bahwa semakin baik manfaat sosial yang terjalin atau social benefits maka loyalitas pelanggan mebel di Lamongan akan semakin baik juga. Hasil penelitian ini mendukung studi yang dilakukan oleh Thurau et al. (2002), Navaro et al. (2004), dan Prayogi (2015).

Berdasarkan hasil penelitian, dapat dijelaskan bahwa special treatment benefits yang meliputi prioritas pelanggan dalam list, potongan harga, produk/layanan yang sigap, harga yang murah, dan produk yang lebih lengkap berpengaruh tidak signifikan terhadap kepuasan pelanggaan mebel di Lamongan karena memiliki nilai koefesien 0,053 dan $p$ value 0,000. Artinya, bahwa special treatment benefits atau manfaat perlakuan istimewa bukan merupakan hal yang vital dalam menciptakan loyalitas pelanggan perusahaan mebel di Lamongan. Temuan dari penelitian ini mendukung studi yang dilakukan oleh Thurau et al. (2002), Kinard dan Capella (2006), dan Prayogi 
(2015). Namun, hasil penelitian ini tidak mendukung studi yang dilakukan oleh Yen dan Gwinner (2003), Molina et al. (2009), dan Briliana (2013).

Hasil pengujian hipotesis menunjukkan bahwa kepuasan pelanggan mebel di Lamongan berpengaruh positif dan signifikan terhadap loyalitas karena $p$ value berada di bawah 0,05 . Hal ini menunjukkan bahwa semakin tinggi tingkat kepuasan pelanggan mebel di Lamongan, maka akan semakin tinggi juga tingkat loyalitasnya. Hasil temuan ini mendukung studi beberapa peneliti, diantaranya adalah Thurau et al. (2002), Yen dan Gwinner (2003), Yen et al. (2009), Navaro et al. (2004), Prayustika (2010), Briliana (2013), dan Prayogi (2015).

\section{Kesimpulan dan Implikasi}

Kesimpulan yang dapat dikemukakan berdasarkan hasil penelitian yang telah di bahas di bagian sebelumnya. Confidence benefits berpengaruh positif dan signifikan terhadap kepuasan pelanggan perusahaan mebel di Lamongan. Hasil penelitian ini menunjukkan bahwa semakin baik manfaat kepercayaan yang didapatkan pelanggan dari perusahaan, maka tingkat kepuasan pelanggan semakin meningkat. Social benefits berpengaruh positif dan signifikan terhadap kepuasan pelanggan perusahaan mebel di Lamongan. Hasil penelitian ini menunjukkan bahwa semakin baik manfaat pertemanan atau sosial yang didapatkan pelanggan dari perusahaan, maka tingkat kepuasan pelanggan semakin meningkat. Special treatment benefits berpengaruh positif dan signifikan terhadap kepuasan pelanggan perusahaan mebel di Lamongan. Hasil penelitian ini menunjukkan bahwa manfaat perlakuan istimewa atau special treatment yang didapatkan pelanggan dari perusahaan, maka tingkat kepuasan pelanggan semakin meningkat.

Confidence benefits berpengaruh positif dan signifikan terhadap loyalitas pelanggan perusahaan mebel di Lamongan. Hasil penelitian ini menunjukkan bahwa semakin baik manfaat kepercayaan yang didapatkan pelanggan dari perusahaan, maka tingkat loyalitas pelanggan semakin meningkat. Social benefits berpengaruh positif dan signifikan terhadap loyalitas pelanggan perusahaan mebel di Lamongan. Hasil penelitian ini menunjukkan bahwa semakin baik manfaat pertemanan atau sosial yang didapatkan pelanggan dari perusahaan, maka tingkat loyalitas pelanggan semakin meningkat. Special treatment benefits berpengaruh negatif namun tidak signifikan terhadap loyalitas pelanggan perusahaan mebel di Lamongan. Hasil penelitian ini menunjukan bahwa special treatment benefits yang diberikan tidak memberikan pengaruh terhadap loyalitas dari pelanggan.

Kepuasan pelanggan berpengaruh positif dan signifikan terhadap loyalitas pelanggan perusahaan mebel di Lamongan. Hasil penelitian ini menunjukkan bahwa semakin baik tingkat kepuasan yang dirasakan pelanggan, maka tingkat loyalitas pelanggan semakin meningkat. Hasil dari penelitian ini diharapkan dapat memberikan manfaat secara praktis maupun teoritis mengenai strategi pemasaran relationship marketing khususnya relational benefit kaitannya dengan kepuasan dan juga loyalitas pelanggan perusahaan mebel di Lamongan. Secara teoritis penjabaran relationship marketing menekankan pada membangun hubungan jangka panjang dengan pelanggan sehingga terdapat suatu manfaat bagi kedua belah pihak yaitu antara pelanggan dan juga perusahaan yang menerapkan strategi ini. Dengan strategi relational benefits melalui confidence benefits, social benefits, dan special treatment benefits diharapkan perusahaan mampu dalam menjaga hubungan baik dengan pelanggan. 


\section{Daftar Referensi}

Alrubaiee, Laith and Nahla Al Nazer. 2010. Investigate the Impact of Relationship Marketing Orientation on Customer Loyalty: The Customer's Perspective. International Journal of Marketing Studies, Vol. 2, No. 1, pp. 155-174.

Arikunto, Suharsimi. 2010. Prosedur Penelitian. Cetakan Keempatbelas. Jakarta: PT. Rineka Cipta.

Briliana, Vita. 2013. Pengaruh Kepuasan, Komitmen, Manfaat Sosial dan Special Treatment Benefits Terhadap Loyalitas Pelanggan. Jurnal Bisnis dan Akuntansi, Vol. 15, No. 1, pp. 57-64.

Dimitriadis, Sergios. 2010. Testing Perceived Relational Benefits As Satisfaction And Behavioral Outcomes Drivers. International Journal of Bank Marketing, Vol. 28, No. 4, pp. 297-313.

Eisingerich, Andreas B, Simon J. Bell. 2006. Relationship Marketing in The Financial Service Industry. Journal of Financial Service Marketing, Vol. 10 No. 4, pp. 8697.

Ferdinand, Augusty. 2002. Structural Equation Modelling Dalam Penelitian Manajemen Aplikasi Model-Model Rumit Dalam Penelitian Untuk Tesis Magister \& Disertasi Doktor. Semarang : BP UNDIP.

Griffin, Jill. 2002. Customer Loyalty, How to Keep it. Josey Bass Gwinner, Kevin P., Dwayne D.

Grembler, and Mary Jo Bitner. 1998. Relational Benefits in Service Industries: The Customers Perpective. Journal Academic Marketing Science, Vol. 26, pp. 101114.

Hurriyati, Ratih. 2005. Bauran Pemasaran dan Loyalitas Konsumen. Bandung: Alfabeta.

Kau, Ah Keng and Elizabeth Wan Yiun Loh. 2006. The effect of service recovery on satisfacation : a comparison between compalaints and non complainants. Journal of Service Marketing, Vol. 20, No. 2, pp. 101-111.

Kinard, Brian R., and Michael L. Capella. 2006. Relationship Marketing: The Influence Of Consumer Involvement On Perceived Service Benefits. Journal of Services Marketing, Vol. 20, pp. 359-368.

Kotler, Hayes, Thomas, \& Bloom. 2002. Marketing Profesional Service. New York: Prentice Hall.

Kotler, 2006. Manajemen Pemasaran Edisi ke Sebelas, Jilid II. Jakarta: Indeks Kelompok Gramedia.

Leverin, Andraez, and Veronica Liljander. 2006. Does relationship marketing improve customer relationship satisfaction and loyalty?. International Journal of Bank Marketing, Vol. 24 No. 4, pp. 232-251.

Lupiyoadi, Rambat dan A. Hamdani. 2008. Manajemen Pemasaran Jasa, Edisi ke Dua. Jakarta: Salemba Empat.

Lovelock, Christopher, and Lauren K. Wright. 2007. Manajemen Pemasaran Jasa. Cetakan Kedua. Jakarta: Indeks.

Molina, Arturo, David Martin Consuegra, Agueda Esteban. 2007. Relational Benefits And Customer Satisfaction In Retail Banking. International Journal of Bank Marketing, Vol. 25 No. 4, pp. 253-271.

Molina, Maria Eugenia, Irene Gil-Saura, and Gloria Berenguer Contri. 2009. Relational Benefits And Loyalty in Retailing: An Inter Sector Comparison. International Journal of Retail \& Distribution Management, Vol. 37 No. 6, pp. 493-509.

Navarro, Mercedes Marzo., Marta Pedraja Iglesias, and Ma Pilar Revera Torres. 2004. The Benefits of Relationship Marketing for The Customer and for The Fashion 
Retailers. Journal of Fashion Marketing and Management, Vol. 8 No. 4, pp. 425-436.

Ndubisi, Nelson Oly, and Chan Kok Wah. 2005. Factorical and Discriminant Analyses of Underpinnings of Relationship Marketing and Customer Satisfaction. International Journal of Bank Marketing, Vol. 23 No. 7, pp. 542-557.

Prayogi, I Made Surya. 2015. Relational Benefit, Kepuasan, dan Loyalitas Pelanggan Pada Bengkel PT. Honda Dewata Motor. Jurnal Manajemen dan Kewirausahaan, Vol. 17, No.1, pp. 11-20.

Rauyruen Papassapa, Kenneth E. Miller. 2007. Relationship Quality As A Predictor Of B2B Customer Loyalty. Journal Of Business Research, Vol. 60, pp. 21-31.

Solimun. 2005. Structural Equation Modelling. Surabaya: Universitas Katolik Widya Mandala.

Sugiyono. 2014. Metode Peneitian Kuantitatif, Kualitatif, dan R\&D. Cetakan Keduapuluh. Bandung: CV. Alfabeta.

Suprapti, Sri. 2009. Perilaku Pasca Pembelian: Sebuah Tinjauan Konseptual untuk Peluang Penelitian. MATRIK, Jurnal Manajemen, Strategi Bisnis.

Suyana, Utama Made. 2007. Aplikasi Analisis Kuantitatif. Denpasar: Sastra Utama.

Sui, Jun Jian, Seyhmus Baloglu. 2003. The Role Of Emotional Commitment In Relationship Marketing: An Empirical Investigation Of A Loyalty. Journal of Hospitality \& Tourism Research, Vol. 27, No 7, pp. 470-479.

Thurau, Thorsten, Kevin P. Gwinner, Dwayne D. Gremler. 2002. Understanding Relationship Marketing Outcomes: An Integration of Relational Benefits and Relationship Quality. Journal of Service Research, Vol. 4, No. 3, pp. 230-247.

Umar, Husein. 2005. Metode Riset Bisnis. Jakarta: PT. Gramedia Pustaka Utama.

Wibowo, Herry Arianto Lestari. 2009. Pengaruh Relationship Marketing terhadap Loyalitas Pelanggan Melalui Kepuasan Pelanggan. Jurnal Aplikasi Manajemen, Vol. 17, No. 4, pp. 818-823.

Yen, Hsiu Ju Rebecca, and Kevin P. Gwinner. 2003. Internet Retail Customer Loyalty. Journal of Service, Vol. 14 No. 5, pp. 483-500.

Yen, Tsai Fa, Hsiou Hsiang Liu, and Chao Lin Tuan. 2009. Managing Relationship Effort to Influence Loyalty : An Emperical Study on The Sun Link Sea Forest and Recreational Park, Taiwan. The International Journal of Organizational Innovation, Vol. 2 No. 2, pp. 179-194.

Yu, Kevin Siu Lung, and Song Yang. 2009. Determinants of Customer Loyalty: An Exploratory Investigation on Relational Benefits in the Context of Customer Club. ANZMAC. pp. 1- 8.

Zheithaml, Valerie A., Mary Jo Bitner, and Dwyne D. Gremler. 2006. Service Marketing-Integrating Customer Focus Across The Firm. $4^{\text {th }}$ Edition. New York: McGraw Hill. 